\title{
PARTICIPAÇÃO PRIVADA NOS SERVIÇOS DE LIMPEZA URBANA
}

\author{
Cesar A. Guimarāes Pereira'
}

I - Definição do Tema; II - Delimitação dos Serviços de Limpeza Urbana; III - Noção de Serviço Público: Atividades Competitivas e Atividades Não Competitivas; IV - Aplicação da Noção de Serviço Público às Atividades de Limpeza Urbana; V - A Configuração Atual da Concessão de Serviços de Limpeza Urbana no Brasil; VI - Competência Administrativa no Caso de Serviços Transmunicipais; VII - Possibilidade de Identificação do Usuário como Requisito da Concessão; VIII - Natureza das Cobranças do Concessionário; IX - O Problema do Inadimplemento dos Usuários; $X-$ Conclusão

\section{I - Definição do tema}

1. O art. 30, V, da Constituição Federal, atribui aos Municípios competência para organizar e prestar, diretamente ou mediante concessão ou permissão, os serviços públicos de interesse local.

Essa competência abrange serviços de limpeza urbana -, envolvendo a remoção, tratamento e disposição final de resíduos domésticos industriais, de estabelecimentos de saúde e os encontrados em áreas públicas.

Nem todos esses serviços vêm sendo prestados sob regime de direito público. É usual a definição da remoção e da destinação de resíduos industriais e de estabelecimentos de saúde, por exemplo, como serviços a ser prestados por empresas privadas diretamente aos geradores dos resíduos (aos quais se atribui a responsabilidade pela destinação desses resíduos especiais). Ainda assim, esses serviços tam-

1 Mestre e Doutorando em Direito do Estado (Direito Tributário) na PUC/SP. O presente estudo corresponde ao material de exposiçāo na mesa redonda "Desafios para a Viabilização de Concessões no Setor de Limpeza Urbana", realizada por IBC - International Business Communications e ABRELPE - Associação Brasileira das Empresas de Limpeza Pública e Resíduos Especiais em 19 de maio de 1999 em São Paulo (SP).

R. Dir. Adm.,

Rio de Janeiro, 216: 75-108, abr./jun. 1999 
bém se relacionam com o interesse coletivo local na remoção e destinação dos resíduos e podem ser legalmente qualificados como serviços públicos de limpeza urbana.

Isso não significa afirmar que todos esses serviços deverão ser prestados diretamente pelos Municípios. Nem mesmo significa impedimento a que parte de tais serviços seja prestada sob regime de direito privado (sem depender de concessão de serviço público). Pretende apenas significar que os municípios têm competência para, à luz do interesse coletivo local, definir legislativamente a forma de prestação de todos os serviços de remoção e destinação de resíduos ${ }^{2}$, bem como para regular (ou "organizar", na linguagem da Constituição) as atividades privadas no setor.

2. A previsão constitucional dessa competência reflete a evolução do papel do Estado (compreendido de modo amplo) quanto à prestação de utilidades materiais em favor dos administrados ${ }^{3}$.

Desde o início do século XX, o Estado deixou a posição de mero disciplinador da prestação de utilidades concretas, na qual dispunha sobre os limites das atividades particulares no fornecimento de bens ou serviços ou, quando muito, cedia o uso de bens públicos (espaço físico para a construção de ferrovias, por exemplo) para a prestação de utilidades por particulares. Seu papel passou a ser conformando de modo positivo. Foi-lhe atribuída participação ativa na realização de utilidades materiais. Evoluiu de uma condição de autoridade espectadora (Estado Liberal) para assumir a missão de intervir diretamente na realidade (Estado Social).

A missão do Estado passou a envolver uma multiplicidade de papéis, que combinam postulados do Estado Liberal (a garantia de um quadro jurídico estável e claro em que se possam desenvolver as capacidades dos particulares) e tarefas positivas, dirigidas à construção de infra-estrutura material e à realização material de atividades de interesse coletivo (típicas da atuação intervencionista que caracteriza o Estado Social).

As atividades de interesse coletivo desenvolvidas pelo Estado podem assumir imensa variedade de contornos. De um lado, vinculam-se à realização imediata dos objetivos constitucionalmente atribuídos ao Estado, como a busca da dignidade humana, mediante a realização de utilidades que assegurem à generalidade da população condições materiais adequadas. De outro, relacionam-se com o desenvolvimento mediato de atividades privadas complementares - através, por exemplo, do fornecimento de bens ou serviços não disponíveis ou economicamente inviáveis no setor privado mas necessários ou convenientes para o desenvolvimento de outras atividades. Há, ainda, atividades expressamente atribuídas ao Estado por decisão constitucional específica (como, no Brasil, a exploração de petróleo — art. 177 da Constituição Federal).

2 Essa competência permitiu. por exemplo, que os municípios de Balneário Camboriú (SC) e Uruguaiana (RS) incluíssem dentre os serviços concedidos os de remoção e destinaçāo de resíduos de estabelecimentos de saúde. resíduos industriais e de construção civil (conforme Edital de Concorrência Pública $n^{\circ} 182 / 97$ e Edital de Concorrência Pública no 02/99, respectivamente).

3 ARIÑO ORTIZ. GASPAR. Economia y Estado - crisis y reforma del sector público. Marcial Pons, Madrid. 1993. pp. 278/284. 
A assunção dessa variedade de tarefas conduziu ao alargamento da estrutura do Estado. Perdeu-se o vínculo inicial das atividades desenvolvidas pelo Estado com o interesse coletivo. O Estado passou a não mais limitar sua atuação à realização de utilidades de interesse coletivo imediato (obras ou serviços públicos) ou dirigidas ao desenvolvimento mediato de atividades privadas (atividade econômica do Estado). Foram abrangidas pela atuação do Estado atividades puramente econômicas, sem vínculo direto nem indireto com o interesse coletivo tal como definido na Constituição Federal.

3. Gaspar Ariño Ortiz, catedrático da Universidad Autónoma de Madrid, propõe uma classificação dos tipos de ação administrativa relacionada com a evolução do papel do Estado ${ }^{4}$. Alude à (a) ação de regulação coativa da iniciativa privada, à (b) ação de fomento (estímulo ou incentivo) não coativa, à (c) ação do Estado como protagonista (pela realização direta de utilidades ou pela contratação, delegação, concessão ou qualquer outra forma de concretização de serviços), à (d) atividade produtiva do Estado (atividade econômica) e à (e) ação de planejamento ou programação.

As atividades de realização material de utilidades relacionam-se com a ação do Estado como protagonista e como agente de produção. No primeiro caso, o Estado desenvolve (sob modalidades e formas variadas) atividades vinculadas de modo imediato ao interesse coletivo. No segundo, ou realiza atividades mediatamente relacionadas com o desenvolvimento coletivo ou assume tarefas que não the são próprias (exatamente por lhes faltar o necessário vínculo com o interesse coletivo).

A referência ao vínculo com o interesse coletivo pode gerar perplexidades. Há inúmeras tarefas desenvolvidas pelo Estado no Brasil aparentemente desvinculadas de um interesse coletivo. Há outras desenvolvidas paralelamente pelo Estado e pelo setor privado, como as de educação e saúde. Tais atividades estatais são objeto de uma decisão constitucional que as engloba nas competências estatais.

4. A evolução do papel do Estado não cessa com a assunção de tarefas concretas a ser desenvolvidas pelo Estado como instrumento para a realização de valores constitucionalmente protegidos (o que se identificou, acima, com a caracterização de um Estado Social).

De protagonista e provedor, o Estado passa a organizador e regulador. Novamente, não se trata de dissociação absoluta com as tarefas antes desenvolvidas. Trata-se, antes, da adoção cumulativa de mais um instrumento de ação do Estado. Além de fixar quadros estáveis para a livre participação privada (Estado Liberal) e de prover diretamente a realização de algumas utilidades em favor dos administrados (Estado Social), o Estado reconhece que a atividade privada é relevante para o atingimento de certos fins constitucionalmente protegidos. Organiza, assim, essa atividade privada, através da instituição de regras e de órgãos destinados a coordenar os esforços privados na realização dos interesses coletivos sem que se descure do interesse econômico privado. 
A atividade reguladora do Estado se desenvolve com complexidade crescente e graduada segundo a importância social da atividade econômica a que se refira. As atividades econômicas com vínculo mais intenso com a realização de interesses coletivos exigirão acompanhamento mais próximo do Poder Público (que poderá chamar para si a titularidade da atividade, concedendo ou permitindo a sua realização por particulares). Outras atividades necessitarão de mera regulação abstrata e de fiscalização realizada (entre outros momentos) no momento da outorga de autorização para que o interessado ingresse no setor econômico.

5. A participação do setor privado na realização das atividades assumidas pelo Estado ocorre de forma variável segundo o tipo de atuação do Estado de que se trate.

Em relação às atividades do Estado como protagonista, a atuação privada pode limitar-se à realização de tarefas mediante contratação administrativa específica. Pode ir além. através da assunção, pelo particular, de riscos econômicos da atividade administrativa, no âmbito de contrato de concessão da exploração de certos serviços. Em casos específicos, pode ser desenvolvida sob regime de permissão.

O Estado não pode realizar atividades econômicas em sentido estrito senão nos termos precisos do art. 173 da Constituição Federal (que autoriza a exploração de atividade econômica em sentido estrito ${ }^{5}$ pelo Estado "quando necessária aos imperativos da segurança nacional ou a relevante interesse coletivo, conforme definido em lei"). A transferência ao setor privado das atividades não enquadráveis no conceito constitucional de atividade econômica em sentido estrito ocorre sob o regime de privatização, mediante o reconhecimento da ausência dos motivos de interesse coletivo que justificariam a sua realização diretamente pelo Estado. As atividades econômicas privatizáveis confundem-se, portanto, com as atividades assumidas pelo Estado sem vínculo com o interesse coletivo definido constitucionalmente. Não há a possibilidade de concessão ou permissão de exploração dessas atividades econômicas precisamente porque não há decisão constitucional (definidora do interesse coletivo) acerca de sua prestação direta ou indireta pelo próprio Estado.

6. A competência do art. $30, \mathrm{~V}$, da Constituição Federal não se limita à prestação direta ou indireta dos serviços públicos de interesse local. Abrange também a organização de tais serviços.

Juan Miguel de La Cuétara Martínez realizou estudo abrangente sobre a regulação dos serviços públicos, referindo que a concessão da exploração dos serviços é uma das técnicas empregadas na regulação ${ }^{6}$. O instrumento de regulação, segundo o autor, varia de acordo com a importância social da atividade regulada, sempre tendo-se por meta "oferecer aos cidadãos prestações cuja existência, acesso, con-

5 Sobre o exame abrangente da atividade econômica como categoria que engloba o serviço público e a atividade econômica em sentido estrito, confira-se EROS ROBERTO GRAU. A ordem econômica na Constituiçào de 1988. Malheiros, $3^{2}$ ed.

6 Aproximación a la regulación de servicio público como nuevo paradigna para la prestación de servicios ecomómicos, em El Nuevo Servicio Público, cit.. p. 94. 
tinuidade e regularidade sejam garantidas pelo Estado" 7 . Essa garantia pode ser materializada através da concessão do serviço público (em que há ingerência direta do Estado na definição de investimentos, fixação de tarifas e no cumprimento do contrato de concessão) ou da adoção de instrumentos que protejam a competição entre os operadores privados - admitidos no mercado por mera autorização, não por concessão de serviços públicos.

7. O presente estudo destina-se a investigar as dificuldades e possíveis soluções para a participação do setor privado na realização de serviços de limpeza urbana.

A generalidade dos municípios no Brasil realiza serviços de limpeza. pública através de órgãos da administração direta (departamentos ou secretarias) ou entidades da administração indireta (autarquias, empresas públicas ou sociedades de economia mista). Tais órgãos ou entidades valem-se de estruturas materiais (equipamentos e pessoal, por exemplo) próprias ou contratam a execução desses serviços junto ao setor privado. A primeira forma de participação do setor privado nos serviços de limpeza urbana consiste na execução de serviços mediante remuneração paga pelo município interessado.

Em número menor de municípios, a participação do setor privado é mais ampla e se desenvolve sob o regime de concessão do serviço público de limpeza urbana. Por definição, o setor privado assume os riscos econômicos da exploração do serviço. A remuneração do concessionário deriva da cobrança de taxas ou tarifas junto aos usuários do serviço, além de receitas complementares (venda de produtos de reciclagem, publicidade ou outras).

Há, ainda, casos de contratos impropriamente qualificados como de concessão em que a remuneração do contratado é assegurada pelo próprio município contratante. A qualificação é imprópria porque a concessão deve ser caracterizada pela assunção de risco pelo concessionário. Contrato de concessão com remuneração assegurada pelo município contratante configura mero contrato de prestação de serviços de operação, que não se confunde com a concessão do serviço. A distinção apresenta uma variedade de consequêencias administrativas e tributárias.

A outorga da exploração de serviços de limpeza urbana sob regime de concessão envolve intensa polêmica.

Há disputa jurisprudencial acerca da constitucionalidade da instituição de taxas de limpeza urbana, tanto em relação à base de cálculo usualmente adotada quanto em relação aos requisitos de especificidade e divisibilidade dos serviços que ensejam a taxa. A concessão de qualquer serviço público é caracterizada pela possibilidade de identificação de um usuário do serviço, responsável pelo pagamento da tarifa que corresponde à receita principal da concessão. Devem-se definir os limites dentro dos quais a discussão acerca da especificidade e da divisibilidade dos serviços de limpeza urbana pode afetar a viabilidade de sua concessão.

De outro lado, a qualificação dos valores cobrados dos usuários como taxa ou tarifa importa em regimes jurídicos absolutamente distintos, o que pode refletir-se na viabilidade (ou não) de financiamento dos serviços pelo setor privado. 
A própria natureza dos serviços envolvidos na limpeza urbana - diretamente relacionados com alguns dos valores mais intensamente protegidos pela Constituição Federal - acarreta dificuldades na outorga de sua exploração ao setor privado. Há grandes restriçōes à possibilidade de interrupção dos serviços em face do inadimplemento dos usuários.

Por fim, a multiplicidade e a dispersão dos usuários cria dificuldades de cobrança da remuneração e torna imprescindível o desenvolvimento de mecanismos de cobrança dotados de praticabilidade.

\section{II - Delimitação dos serviços de limpeza urbana}

8. Em trabalho apresentado no $2^{0}$ Simpósio Internacional de Destinação do Lixo, em junho de 1997, J. H. Penido Monteiro anotou que as atribuições usualmente relacionadas com a limpeza urbana, em sentido mais amplo, compreenderiam as seguintes: (a) coleta regular do lixo urbano, (b) coleta de resíduos de unidades de trato de saúde, (c) transferência e transporte, (d) usinas de incineração, (e) usinas de compostagem e reciclagem, (f) aterros sanitários, (g) varrição dos logradouros públicos, (h) limpeza e manutenção de praças e jardins, (i) capinação e raspagem, (j) limpeza de bocas-de-lobo (bueiros), (l) desobstrução de ramais e galerias, (m) desinfetação e desinfecção, (n) podas, (o) pintura de meio-fio, (p) lavagem de logradouros públicos, (q) remoções especiais de entulhos, galhadas etc. e (r) limpeza de praias.

Porém, logo adiante, o estudioso adota um conceito restrito (ou essencial) de limpeza urbana, compreendido pelas seguintes atividades: " a coleta domiciliar e de resíduos de unidades de saúde, a limpeza de logradouros, a transferência e o transporte até o destino final, a operação de tratamento e de unidades de destinação final" 8 .

O presente estudo não pressupõe uma definição precisa do objeto dos serviços de limpeza urbana - até porque a sua definição depende, em cada caso concreto, da escolha técnica do município competente para o desenvolvimento dos serviços. Pretende-se aqui apenas o estabelecimento de parâmetros que possam ser aplicados às tarefas concretamente eleitas pelo município competente em cada caso.

Assim, as discriminações acima serão adotadas apenas como orientação de raciocínio, não como definição exaustiva do conceito de limpeza urbana.

III - Noção de serviço público: atividades competitivas e atividades não competitivas

9. A definição inicial do objeto das atividades de limpeza urbana permite apurar, desde logo, a existência de uma infra-estrutura material, consistente em usinas de

8 Ob. Cit., pp. 23. Com algumas alterações, essa é a configuração dos serviços concedidos em Balneário Camboriú (SC) e Uruguaiana (RS) - nota 2 acima. 
compostagem ou reciclagem, aterros sanitários, unidades de desinfecção, incineradores e outros equipamentos necessários para a operação de “ unidades de destinação final" (indicada como atividade essencial de limpeza urbana).

Essa infra-estrutura material é integrada por obras públicas, que consistem na "construção, reparação, edificação ou ampliação de um bem imóvel pertencente ou incorporado ao domínio público" " Não se trata, neste caso, de obras fruíveis diretamente pelos administrados, mas instrumentais para a prestação de serviços vinculados à limpeza urbana. Correspondem, assim, à noção de obra pública como “o suporte material para a prestação de um serviço: a fruição do serviço é a fruição da própria prestação, assim depende sempre integralmente dela" 10 .

O núcleo da noção de limpeza urbana está na realização de um serviço. A definição desse serviço como público dependerá da sua submissão a um regime de direito público - em face de sua eleição constitucional ou legal como atividade sujeita a esse regime.

10. Celso Antônio Bandeira de Mello sintetizou o conceito de serviço público como "toda atividade de oferecimento de utilidade ou comodidade material fruível diretamente pelos administrados, prestado pelo Estado ou por quem lhe faça as vezes, sob um regime de direito público - portanto consagrador de prerrogativas de supremacia e de restrições especiais - instituido pelo Estado em favor de interesses que houver definido como próprios no sistema normativo" ".

O conceito vem definido sob três aspectos. Materialmente ("serviço"), consiste em uma prestação, no oferecimento de uma utilidade material; formalmente ("público"), pressupõe a sujeição ao regime de direito público (ou seja, uma escolha normativa expressa ou implícita quanto à qualificação do serviço como público); subjetivamente, é prestado pelo Estado ou por quem lhe faça as vezes (como um concessionário do serviço, por exemplo). O que torna público o serviço não é apenas o seu vínculo com um suposto interesse coletivo mas uma determinação normativa - ainda que implicitamente derivada da própria definição (também normativa) do interesse coletivo.

Marçal Justen Filho agrega a essa definição a noção de "instrumentalidade do serviço para a realização dos fins da comunidade" 12 , como forma de aferir "se $o$ direito pode submeter qualquer serviço ao regime de direito público, transformando-o em público". Segundo o doutrinador, "definir serviço público pressupōe definir e dimensionar o Estado e os valores juridicos fundamentais. $O$ conceito de serviço público é um conceito reflexo. Deriva do modelo constitucional assumido pela comunidade, inclusive no tocante à função e ao papel que a própria comunidade reserva para si própria"13.

9 BANDEIRA DE MELlO, CELSO ANTÔNIO. Curso de Direito Administrativo. Malheiros, $11^{2}$ ed., 1999 , p. 482.

10 BANDEIRA DE MELLO, CELSO ANTÔNIO, ob. cit., p. 482.

11 BANDEIRA DE MELLO, CELSO ANTÔNIO, ob. cit., p. 477.

12 Concessões de Serviços Públicos, Dialética, 1997, p. 58.

13 Concessõe.... p. 58 
Mais adiante, Marçal Justen Filho aponta que "Uma consideração inafastável acerca de serviço público, portanto, relaciona-se com sua aptidão para realizar certos valores fundamentais assumidos pela Nação. Bem por isso, é impossível despublicizar certos serviços públicos no Brasil, pois sua prestação foi garantida constitucionalmente, como via de promover a dignidade da pessoa humana, a eliminação das desigualdades e outros valores fundamentais. Não se admite que o Estado se recuse a promover tais valores, nem mesmo diante da invocação de ausência de lucratividade. Aliás, há serviços que são transformados em públicos precisamente porque, em face dos encargos a eles relacionados, nunca seriam desempenháveis pela iniciativa particular, tendo em vista sua incompatibilidade com os parâmetros de lucratividade que norteiam a atuação tipicamente privada" ${ }^{14}$.

Essas noções são particularmente aplicáveis aos serviços envolvidos na limpeza urbana. Em grande parte, trata-se de serviços diretamente vinculados à promoção da dignidade humana e à preservação da saúde pública. Além disso, envolvem a necessidade de universalização do atendimento - sem que se possa suprimir a exigência de cobertura universal por motivos relacionados com a ausência de lucratividade ou com a dificuldade de arrecadação.

11. A preocupação com os serviços que pressupõem a universalização de atendimento (os chamados "serviços universais") vem inspirando a adoção de soluções inovadoras no direito europeu. $\mathrm{O}$ exame de tais soluções parece-nos imprescindível para a compreensão dos problemas relacionados com a participação privada nos serviços de limpeza urbana.

Em estudo publicado em $1997^{15}$, GASPAR ARIÑO ORTIZ defendeu que a compreensão adequada da evolução do papel do Estado deve conduzir à adoção de um modelo de serviços públicos competitivos - em que se afasta a noção de titularidade estatal dos serviços (que está na base, inclusive, da concessão de serviços públicos) e se premia a sua regulação aberta e a sua prestação em regime de concorrência (com liberdade de prestação do serviço mediante autorização, liberdade de investimentos e liberdade de fixação de preços, como em qualquer atividade econômica privada). Os serviços públicos competitivos, portanto, nem mesmo seriam objeto de concessão: não haveria titularidade do Estado sobre o serviço, que poderia ser prestado mediante mera autorização administrativa (no exercício de poder de polícia).

Segundo o doutrinador - e aqui está a chave para a compreensão do seu raciocínio --, deve-se reconhecer a distinção entre o serviço (como um setor de atividades) e as diversas atividades que o compõem. E mais: deve-se promover uma desintegração vertical (unbundling) da prestação, identificando as atividades relacionadas com a infra-estrutura e os serviços propriamente ditos, passíveis de prestação em regime competitivo. Para Gaspar Ariño, os objetivos dessa desintegração

14 Concessões... p. 59

15 El Nuevo Servicio Público, obra conjunta com CUÉTERA, J. M. DE LA, e MARTÍNEZ LÓPEZMUÑIZ, J. L., Marcial Pons, 1997, pp. 25/26. 
vertical são "1) a distinção entre atividades potencialmente competitivas e não competitivas, com áplicação de um regime juridico distinto a umas e outras como veremos adiante, e 2) a transparência informativa, que é conditio sine qua non para uma correta regulação, com eliminação de subvenções cruzadas entre os distintos serviços" 16 .

Com base nessas premissas, o doutrinador afirma ser possível identificar, em cada setor, atividades competitivas e atividades não competitivas. $O$ objetivo dessa identificação consiste sempre no aperfeiçoamento dos instrumentos para a atuação do Estado na garantia de obtenção, pelos particulares, de serviços públicos caracterizados pela eficiência, suficiência, continuidade e regularidade. Nem sempre a "publicização" do serviço, com a intervenção privada apenas mediante concessão ou permissão, é o caminho mais adequado para a realização do interesse público.

O regime jurídico das atividades competitivas caracteriza-se por (a) liberdade de entrada, de forma que todos os que preencham certos requisitos mínimos possam prestar os serviços (mediante autorização administrativa vinculada), (b) livre acesso dos prestadores à infra-estrutura necessária à prestação dos serviços, (c) liberdade de contratação e de formação de preços, e (d) liberdade de investimentos, sem compromisso vinculante quanto a investimentos e taxas de retorno ${ }^{17}$. Esses instrumentos são indispensáveis para que se possa realizar a competição - que é pressuposto da eficiência na prestação dos serviços objeto de tais atividades competitivas.

Ainda segundo o doutrinador, as atividades de natureza não competitivas seriam de duas espécies. Tais atividades, por seu maior vínculo com o interesse público, são mais vocacionadas à prestação em regime de concessão ou permissão.

A primeira atividade não competitiva relaciona-se com a instalação e gestão de infra-estruturas, que "são necessariamente de uso comum e sobre as mesmas os distintos operadores podem oferecer serviços singularizados" ${ }^{18}$. É o que já se passa, no Brasil, com os serviços de navegação aérea ou de transporte rodoviário: os aeroportos e rodovias são objeto de monopólio natural, atividade não competitiva de infra-estrutura; essa infra-estrutura é utilizada, com liberdade e igualdade de acesso, pelos inúmeros prestadores de serviço individuais.

A segunda espécie vincula-se às prestações de serviço essencial universal, que são precisamente "aquelas modalidades a que o mercado, por si só, não daria resposta e que a autoridade entende que devem estar cobertas porque constituem um padrão mínimo de serviço a que todos têm direito" ${ }^{19}$. Segundo Ariño. "Neste caso, a concorrência não é possível porque não há oferta. E não há porque o custo de tais prestações jamais seria coberto pelo preço que por elas se poderia pagar, e ninguém estaria interessado em concorrer. Em tais casos, a regulação de novo intervém, impondo a prestação obrigatória a qualquer dos operadores do setor" ${ }^{20}$.

16 El Nuevo... p. 27.

17 El Nuevo... p. $27 / 30$.

18 El Nuevo... p. 30.

19 El Nuevo... p. 31.

20 El Nuevo... p. $31 / 32$. 
A aplicação adequada dessa discriminação entre atividades competitivas e atividades não competitivas pressupõe, entre outras premissas (já referidas acima), a "não qualificação como serviço público de uma atividade ou setor em seu conjunto, mas apenas de algumas tarefas, missões, atuações concretas dentro daquele", de forma a definir, em cada setor, "quais são as obrigaçōes ou encargos de serviço público, isto é, de serviço universal, obrigatório, que deva ser garantido, como missão ou tarefa de interesse geral em cada setor concreto" 21 . Para exemplificar seu pensamento, Ariño menciona tarefas relacionadas com diversos setores específicos: "no transporte será a cobertura de determinadas linhas regulares (mas não qualquer transporte); no correio, o serviço básico postal de cartas e certificados com caráter universal (mas não o serviço de encomendas ou transporte urgente); nas telecomunicações, o serviço básico telefônico com caráter universal (mas não os serviços de valor agregado, a telefonia móvel ou as redes locais a cabo); na eletricidade, o transporte em alta tensão pela rede geral peninsular e a distribuição universal a todo pequeno consumidor final (mas não a geração elétrica, nem a venda por atacado, nem o fornecimento a grandes consumidores)" 22.

Santiago Muñoz Machado, da Universidad Complutense de Madri, alude ao regime jurídico dos serviços universais no âmbito da União Européia ${ }^{23}$. Menciona a comunicação da Comissão sobre os serviços de interesse geral na Europa, datada de 26 de setembro de 1996, que distingue tais serviços em (a) serviços de interesse geral, (b) serviços de interesse econômico geral, (c) serviços públicos, e (d) serviços universais. Segundo o doutrinador, o setor em que a noção de serviços universais está mais avançada é o de telecomunicações, no qual consiste, "por exemplo, em manter para todos os cidadãos a disponibilidade do serviço de telefonia básica, ainda que as empresas que o operem tenham uma tendência a não prestá-lo naquelas zonas do território em que não seja rentável, por razóes geográficas ou de desagregação da população" ${ }^{24}$. Muñoz Machado adverte que "a privatização e a liberalização não podem prejudicar o acesso dos cidadãos a serviços básicos" 25 .

O doutrinador menciona, ainda, possibilidades de solução — previstas no âmbito da União Européia - para a questão do financiamento do serviço universal (ainda considerando os serviços de telecomunicações): "sua prestação [do serviço universal] por todos ou por apenas algum dos operadores; em qualquer alternativa mantém-se como obrigação fixa o dever de todos de contribuir para financiá-lo; no caso em que todos contribuam, pode-se estabelecer um fundo comum ou pagar o serviço ao operador que realmente o preste; para estabelecer o custo real do serviço é necessário impor uma separação entre o serviço universal e as demais atividades do operador, ao menos mediante uma contabilização dos custos; o custo que se deve

21 El Nuevo... p. 32. Em sentido similar, DE LA CUÉTARA MARTÍNEZ adverte para a inconveniência de uma publicatio genérica, recomendando a indicação precisa e concreta das obrigações de serviço público que devem ser cumpridas pelos operadores (ob. cit., pp. 98/99).

22 El Nuevo... p. 32

23 Servicio público y mercado, Civitas, v. I, 1998, p. 317.

24 Ob. cit., p. 320

25 Ob. cit., p. 320 
cobrir é o custo líquido. Quem administrar o fundo deve fazê-lo de modo neutro" 26 . A propósito, o modelo adotado pela atual Lei Geral de Telecomunicações, no Brasil, contempla o financiamento do serviço universal por todos os prestadores, através de contribuições para um fundo comum.

12. Parece-nos, portanto, que os critérios definidos por Gaspar Ariño devem informar o exame de quais serviços podem ser tornados públicos pelo direito - vale dizer, ser objeto de publicatio.

Tal como apontado por Marçal Justen Filho, não há liberdade ampla para a publicização dos serviços. Parece-nos que somente as atividades integrantes de serviços configuradas como instrumentais para a realização de objetivos fundamentais do Estado podem ser tornadas públicas. Adotando-se a classificação de Ariño, não podem ser públicas (e, portanto, devem ser prestadas pelo setor privado, ainda que mediante regulação e autorização administrativa prévia) as atividades competitivas. Públicas - e passíveis de prestação diretamente pela Administração ou segundo regime de concessão ou permissão — devem ser as atividades não competitivas, relacionadas com a infra-estrutura e com os serviços universais.

Como já se apontou, a publicatio e a subseqüente concessão ou permissão do serviço público são apenas um dos vários instrumentos de regulação. As atividades competitivas integrantes de um setor de interesse coletivo (como o de limpeza urbana) não deixam, por ser competitivas, de ter relevância coletiva. Submetem-se, em vista disso, à regulação pelas regras legais e regulamentares do ente político competente para a disciplina, organização ou regulação do setor de atividade econômica a que se referem tais atividades.

IV - Aplicação da noção de serviço público às atividades de limpeza urbana

13. Nos termos do art. 175 da Constituição Federal, "incumbe ao Poder Público, na forma da lei, diretamente ou sob o regime de concessão ou permissão, sempre através de licitação, a prestação de serviços públicos".

A concessão pressupõe, portanto, a titularidade pública sobre certo serviço. $\mathrm{O}$ exame da viabilidade da concessão ao setor privado da exploração de serviços depende da constatação de que o serviço é vinculado a determinado ente do Poder Público. As atividades que não consistem em serviço público não são passíveis de concessão mas podem ser prestadas com liberdade pelo setor privado (observadas a regulação existente e a eventual necessidade de prévia autorização, em vista das circunstâncias já expostas).

A Lei $\mathrm{n}^{0}$ 9.074/95 estabeleceu a necessidade de lei para autorizar a outorga, pela Administração, de concessão ou permissão de serviços públicos, "dispensada a lei autorizativa nos casos de saneamento básico e limpeza urbana" (art. $2^{\circ}$, caput). Esse dispositivo merece exame, no presente estudo, sob dois ângulos: primeiro,

26 Ob. cit., p. 323 . 
quanto à viabilidade (ou não) de dispensa de lei autorizativa nos dois casos citados; depois, quanto ao conceito de "limpeza urbana" pressuposto pela lei.

13.1. O primeiro ponto citado foi objeto de análise abrangente por Marçal Justen Filho, para quem o art. 175 da Constituição Federal exige prévia autorização legal para a outorga de qualquer concessão de serviço público ${ }^{27}$.

Essa conclusão deriva tanto de uma interpretação literal como sistemática do dispositivo constitucional ${ }^{28}$. Além disso, é coerente com o entendimento do doutrinador acerca da qualificação das cobranças do concessionário como tarifa e não como taxa: para Marçal Justen Filho, a lei autorizativa faz com que o regime tributário possa ser legitimamente excepcionado no caso da concessão de serviço público $^{29}$.

No ponto em que pretende dispensar a autorização legislativa no caso dos serviços de limpeza urbana, o art. $2^{\underline{0}}$ da Lei $n^{0}$ 9.074/95 é inconstitucional. A concessão de tais serviços outorgada sem prévia lei autorizativa é inválida e passível de anulação na forma do art. 59 da Lei $\mathrm{n}^{\mathrm{0}}$ 8.666/93 (mediante a indenização do concessionário por danos emergentes e lucros cessantes ${ }^{30}$ ).

13.2. De outro lado (e abstraindo-se a questão relativa à dispensa inválida de prévia autorização legislativa), a norma geral veiculada através do dispositivo legal acima indicado não define o conteúdo material do serviço público de limpeza urbana. Confirma o caráter público desse serviço e o submete a prévia concessão para exercício pelo setor privado. Porém, não define materialmente as atividades envolvidas na limpeza urbana.

A regra deve ser interpretada de forma coerente com a advertência já formulada acima sobre a impossibilidade de a lei (infraconstitucional) tornar públicas atividades competitivas que integrem certo setor de serviços. Não se pode supor que, ao aludir a "limpeza urbana", o art. $2^{\underline{0}}$ da Lei $\mathrm{n}^{\underline{0}} 9.074 / 95$ tenha submetido a prévia outorga de concessão ou permissão a integralidade das atividades relacionadas com a limpeza urbana.

A referência da lei deve ser interpretada como significando apenas as atividades não competitivas abrangidas na noção de limpeza urbana. $\mathrm{O}$ art. 175 da Constituição Federal não permite que serviços (ou atividades) não materialmente qualificáveis como públicos possam ser excluídos da esfera de liberdade de iniciativa particular e submetidos a regime de direito público. As atividades competitivas integrantes de tais serviços são asseguradas ao setor privado, na forma do art. 173 da Constituição Federal. Afinal, " a exploração direta de atividade econômica pelo Estado só será permitida quando necessária aos imperativos da segurança nacional ou a relevante interesse coletivo, conforme definido em lei" (art. 173, caput, da Constituição Fe-

27 Ob. cit., p. 391.

28 Concessōes... pp. $389 / 390$.

29 Concessóes... p. 144.

30 Segundo MARÇAL JUSTEN FILHO, é inconstitucional a restrição pelo art. 59 da Lei $n^{\mathfrak{Q}} 8.666 / 93$ do montante da indenização apenas aos valores do que tiver sido executado e dos prejuízos comprovados. devendo abranger também os lucros esperados pelo particular (Comentários à Lei de Licitaçōes $e$ Contratos Administrativos, Dialética. 1998. pp. 499/500). 
deral). Havendo a possibilidade de competição (ou seja, tratando-se de atividades competitivas), é, em princípio, viável sua prestação pelo setor privado. Também em princípio, não há interesse coletivo apto a permitir ao Estado a assunção da referida atividade com fundamento no art. 173 da Constituição Federal.

Novamente, isso não impede que a regulação dos serviços competitivos se dê por outra forma (diversa da concessão e permissão de serviços públicos). Devem-se adotar outros mecanismos que assegurem a eficiência global do sistema.

Note-se que a presente exposição parte da distinção entre serviços e as atividades que o compõem e, quanto a estas, entre atividades competitivas e atividades não competitivas. Portanto, ao se afirmar que as atividades competitivas que integram o serviço de limpeza urbana consistem em atividades econômicas excluídas (em princípio) da esfera de atuação do Estado como prestador ou concedente de serviços, não se está negando a natureza pública do serviço de limpeza urbana nem confundindo serviço público e atividade econômica do Estado. O que se está fazendo é uma delimitação do conceito de serviço público de limpeza urbana (de titularidade estatal) para abranger apenas as atividades não competitivas de infra-estrutura e de serviço universal. As demais podem ser prestadas pelo setor privado, mediante autorização e de acordo com a regulação eventualmente editada pelos municípios competentes (ou pela União, no exercício de sua competência para a edição de normas gerais).

14. O critério para a definição do que são atividades não competitivas de infra-estrutura e de serviço universal envolve condicionantes técnicas que não podem ser examinadas neste estudo.

Parece-nos possível, porém, indicar alguns parâmetros fundamentais. $\mathrm{O}$ serviço universal de limpeza urbana deve assegurar a todos os cidadãos a remoção dos resíduos sólidos domésticos, com periodicidade razoável. Deve, além disso, ocuparse da remoção dos resíduos produzidos por estabelecimento de saúde, com a segurança e a periodicidade necessárias para a garantia da saúde pública. Deve, também, preservar um nível mínimo de limpeza dos logradouros públicos (com remoção dos resíduos correspondentes).

As atividades de infra-estrutura parecem-nos envolver fundamentalmente a construção e a operação de aterros sanitários, usinas de compostagem, incineradores e locais para separação de materiais recicláveis, dentro de um limite mínimo de capacidade.

A abrangência do serviço universal e das atividades de infra-estrutura deve ser definida com base em lei e à luz do estado da técnica. As preocupações ambientais podem agregar-se às de saúde pública para ampliar os níveis mínimos de serviços e infra-estrutura.

Para além dos serviços universais e das atividades de infra-estrutura, restam inúmeras atividades relacionadas com a limpeza urbana passíveis de atuação competitiva dos operadores. De certo modo, isso já corresponde à realidade das atividades de limpeza urbana. Serviços especiais como o de remoção e destinação de lixo industrial e de estabelecimentos de saúde ou a coleta e separação de material reciclável já são prestados por pessoas privadas independentemente de concessão municipal. 
Não há limite definido para tais serviços especiais, que podem ser modelados segundo a necessidade do mercado e a capacidade técnica dos operadores. Algumas atividades competitivas na área de limpeza urbana são, entre outras, a remoção de resíduos industriais; a prestação de serviços especiais de remoção de entulhos, galhadas, móveis, detritos de construção civil etc.; a prestação de serviços de podas; a remoção de resíduos com frequiência superior à mínima exigida; a operação alternativa de aterros sanitários, usinas de compostagem, incineradores e locais para separação de material reciclável, mediante a cobrança de preços pagos pelos responsáveis pela coleta.

A definição de tais atividades competitivas deve ser negativa, reputando-se passível de realização pelo setor privado aquilo que não se configurar como atividade não competitiva (de infra-estrutura ou relativa a serviço universal). É claro que o conceito de serviço universal está em evolução continua ${ }^{31}$ e, na medida em que se ampliam as opções tecnológicas, eleva-se o nível mínimo de satisfação para que se considere adequadamente prestado o serviço universal. Porém, o conteúdo das atividades não competitivas, submetidas pela lei ao regime de direito público, delimita negativamente as atividades competitivas que devem ser reservadas ao setor privado.

É viável, portanto, que o nível mínimo de infra-estrutura seja atendido com um incinerador de resíduos de estabelecimentos de saúde (por exemplo) mas que se autorize a instalação de outros que venham a competir com esse primeiro. É também possível que se conceda a operação de unidade de desinfecção ou incinerador dessa espécie de resíduos, determinando-se que todos os operadores da coleta devam destinar os resíduos a essa unidade ou a esse incinerador.

O fundamental é que seja assegurado o livre acesso (mediante remuneração) às instalações de infra-estrutura. Seria cogitável, por exemplo, que os grandes geradores de lixo (condomínios, clubes, empresas etc.) pudessem, em lugar de utilizar o serviço público de coleta, valer-se de transporte próprio para remover o lixo até o local designado para a sua destinação. Nesse caso, o próprio usuário teria acesso (pago) à infra-estrutura ${ }^{32}$.

É indispensável a segurança do município quanto à existência e à eficiência dos serviços de limpeza urbana até um certo nível. Esse nível mínimo é o que caracteriza os serviços universais e as atividades de infra-estrutura (ambos não competitivos) e recomenda a sua prestação direta ou mediante concessão ou permissão pelo Poder Público (ou seja, a adoção de mecanismos mais rígidos de regulação). A competição poderá ocorrer nas atividades situadas além desse nível reputado indispensável para a realização das utilidades e valores definidos pela Constituição e pela Lei como objetivos a ser perseguidos pelo Poder Público.

15. A evolução do papel do Estado em relação à prestação de serviços públicos deverá conduzir a uma delimitação restritiva dos serviços de limpeza urbana passíveis de concessão ou permissão.

31 MUÑOZ MACHADO, SANTIAGO. Ob. cit., p. 320.

32 Discussão similar está em curso quanto ao acesso de grandes consumidores às geradoras de energia elétrica, sem a intermediação das distribuidoras (Gazeta Mercantil, edição de 17 de maio de 1999, p. A-10). A matéria está aguardando regulação da Agência Nacional de Energia Elétrica - ANEEL. 
Isso não significa uma ampliação dos serviços a ser prestados diretamente pelo Poder Público, mas a sua drástica redução (ou, eventualmente, eliminação). Todas as atividades relacionadas com a limpeza pública podem ser, em tese, prestadas por conta e risco da iniciativa privada. Em alguns casos (os de importância social mais intensa), a prestação ocorrerá sob o regime de concessão ou permissão. Nos demais, o regime será o de mercado, envolvendo regulação mas não a concessão do Poder Público.

15.1. Deverão ser prestadas (diretamente ou mediante concessão) pelo Estado as atividades não competitivas de limpeza urbana, relacionadas com a infra-esttutura e com o atendimento do serviço universal de limpeza urbana - embora não se exclua, ao menos em tese, a modelagem da prestação de tais serviços de forma a assegurar a competição, temperada por obrigações de direito público, também em relação à arte dessas atividades supostamente não competitivas.

$\mathrm{Na}$ hipótese de prestação de tais serviços mediante concessão, haverá distinção entre a atuação de infra-estrutura e a de serviço universal.

No primeiro caso, os usuários do serviço corresponderão aos operadores do serviço universal e das atividades competitivas. A remuneração do concessionário corresponderá à tarifa cobrada de tais operadores e a outras receitas acessórias (derivadas, por exemplo, da venda de produtos para reciclagem). Em princípio, será cabível a aplicação do art. $6^{\circ}$, $3^{\circ}$, II, da Lei no $8.987 / 95$, que permite a interrupção do serviço por inadimplemento do usuário) na prestação desses serviços. $O$ pagamento das tarifas devidas ao operador das atividades de infra-estrutura deve ser previsto como pressuposto para a manutenção da autorização para os serviços de coleta, por exemplo - o que exige, para sua eficiência, uma pluralidade de operadores de coleta, de modo a que a falta do operador inadimplente possa ser suprida com eficiência.

O segundo caso envolve a prestação de serviços diretamente aos usuários finais (cidadãos), através da remoção de resíduos sólidos domiciliares e de estabelecimentos de saúde, bem como da remoção de resíduos de logradouros públicos. A remuneração do concessionário (ou dos vários concessionários) corresponderá à tarifa cobrada diretamente dos usuários, o que envolve risco de inadimplência. Esse risco deve ser suportado pelo conjunto do sistema, não isoladamente pelo prestador dos serviços universais. Devem-se prever mecanismos - como, por exemplo, a constituição de um fundo mediante contribuições dos vários operadores — destinado à cobertura desse risco (sem prejuízo dos mecanismos adequados de cobrança administrativa e judicial a ser adotados pelo prestador dos serviços universais).

A Lei $n^{\circ}$ 9.472/97 (Lei Geral de Telecomunicações) prevê, nos arts. 80 e 81, a existência de um fundo de universalização constituído por recursos públicos e por recursos oriundos de contribuição (a ser prevista em lei) dos prestadores de serviços de telecomunicações. $\mathrm{O}$ art. 81, parágrafo único, prevê que, na ausência do fundo, serão possíveis subsídios e cobranças de adicionais.

A constituição de um fundo com recursos privados através de lei municipal encontraria dificuldade nos arts. 145, II, e 149 da Constituição Federal. Dependeria da cobrança de valor a ser pago pelas empresas que realizassem atividades competitivas de limpeza urbana. Esse valor não poderia ser taxa vinculada à autorização 
para realizar a atividade (art. 145, II. da Constituição) porque não seria vinculada à atividade de polícia mas à subvenção dos serviços universais. Também não poderia ser contribuição para intervenção no domínio econômico (art. 149 da Constituição), em face da competência privativa da União Federal para a instituição dessa espécie de tributo.

Além disso, a constituição de um fundo de universalização com recursos públicos poderia enfrentar obstáculo na impossibilidade de haver garantia de receita mínima ao concessionário de serviços públicos (em face do veto presidencial ao art. 24 da Lei $\left.n^{0} 8.987 / 95\right)$. Não nos parece, porém, que se estaria diante de garantia de receita mínima neste caso. A situação corresponde apenas à conjugação entre a necessidade de continuidade de serviço público essencial e a ilicitude de se impor ao concessionário o sacrifício da prestação dos serviços sem o correspondente pagamento. É possível, assim, a constituição de fundo de universalização municipal com recursos públicos. Não é cabível, porém, que o fundo seja destinado a cobrir indiscriminadamente os casos de inadimplência; sua finalidade deve ser estritamente vinculada à universalização do serviço sem prejuízo especial para o concessionário.

15.2. As demais atividades deverão ser prestadas sob regime de direito privado - ainda que mediante regulação e autorização prévia do município em que as atividades devam ser realizadas.

A regulação deve prever os deveres do operador quanto às atividades não competitivas de limpeza urbana. Porém, não se estará diante de concessão (nem de permissão) de serviço público. Haverá mera atividade privada, embora submetida a regulação.

A remuneração do operador das atividades competitivas será preço de direito privado, fixado livremente entre o operador e os usuários dos serviços prestados. Não haverá controle público sobre contratações, investimentos ou a formação de preços.

Nada impede que as atividades não competitivas e competitivas sejam realizadas pelo mesmo operador. Porém, haverá a necessidade de nítida segregação entre os custos e receitas de cada atividade - inclusive diante da natureza jurídica distinta dos valores cobrados pela operação das atividades de infra-estrutura, de serviço essencial e de atividades competitivas.

16. Está em tramitação na Câmara dos Deputados desde 1992 o Projeto de Lei $\mathrm{n}^{\circ} 3.333$, de autoria do Dep. Fábio Feldmann, destinado à instituição da política nacional de resíduos sólidos.

$\mathrm{O}$ art. $3^{\circ}$ do Projeto define seis categorias de resíduos sólidos, sob as denominações de resíduo domiciliar, resíduo público, resíduo industrial, resíduo de unidades de serviços de saúde, resíduos provenientes de embalagens de pesticidas nas áreas rurais e resíduos de fontes especiais.

$\mathrm{O}$ art. $4^{\circ}$ do Projeto estabelece que " $A$ organização $e$ o gerenciamento dos sistemas de manipulação, acondicionamento, armazenamento, coleta, transporte, tratamento e disposição final dos resíduos sólidos constituem serviço público de caráter essencial". . Não distingue entre atividades competitivas e não competitivas, submetendo ambas ao regime de direito público. Porém, estabelece a possibilidade de concessão ou permissão apenas quanto aos serviços de "coleta, o transporte, $o$ 
tratamento e disposição final dos resíduos domiciliares, públicos e de unidades de serviços de saúde" (art. $5^{\circ}$, caput e $\S 1^{\varrho}$ ) — que correspondem, de modo aproximado, às atividades relativas aos serviços universais. Em relação aos resíduos industriais, o Município deverá exigir um planejamento quanto à sua disposição por parte da indústria (art. $\left.6^{\circ}\right)$. O Município poderá, ainda, cobrar tarifas por "serviços especiais" relacionados com resíduos de atividades de comércio e de saúde e com o lixo industrial (art. $8^{\circ}$ ). O Projeto dispõe, ainda, de forma detalhada, acerca dos parâmetros da coleta, transporte, tratamento e disposição final dos resíduos (arts. 14 a 35).

Embora não de modo direto, o Projeto consagra critérios próximos dos referidos neste estudo acerca da distinção entre atividades competitivas e não competitivas de limpeza urbana. Reserva à concessão de serviços públicos certas atividades essenciais, relacionadas com as categorias mais básicas de resíduos sólidos. Prevê regulamentação detalhada, porém, quanto a todas as categorias. Não impede que serviços relacionados com as outras categorias - e, mesmo, serviços "especiais" relacionados com as categorias essenciais - sejam prestados pelo setor privado sob regime diverso do de concessão ou permissão de serviços públicos.

O projeto de lei está em andamento na Comissão de Seguridade Social e Família desde março de 1999.

\section{V - A configuração atual da concessão de serviços de limpeza urbana no brasil}

17. Não há, atualmente, previsão normativa expressa da segregação entre atividades competitivas e não competitivas no âmbito da limpeza urbana - embora isso não impeça, como se apontou, que o art. $2^{0}$ da Lei $n^{0}$ 9.074/95 seja interpretado de modo a submeter ao regime de concessão de serviços públicos apenas as atividades não competitivas desse setor.

Além disso, as legislações municipais (inclusive de natureza tributária) consagram a natureza pública dos serviços de limpeza urbana, sem discriminar entre atividades competitivas e não competitivas - e, ao contrário, normalmente atribuindo aos órgãos responsáveis pela realização dos serviços competência para atuação plena na área de limpeza urbana ${ }^{33}$. É notório, porém, que nas atividades relacionadas com as áreas menos sensíveis para a saúde pública os serviços públicos vêm assumindo um caráter subsidiário, atuando apenas na ausência de prestadores privados. Já existe, de modo não ordenado, uma dissociação prática entre atividades públicas e atividades privadas de limpeza urbana - embora a generalidade dos municípios assuma subsidiariamente a responsabilidade pela remoção e destinação de todas as espécies de resíduos encontráveis em seu território.

A atuação organizada do setor privado na área de limpeza urbana fora do regime de concessão de serviços públicos, portanto, pressupõe a disciplina legal da segregação entre atividades competitivas e não competitivas de limpeza urbana (de modo

33 Sobre o tema, confira-se o estudo de J. H. PENIDO MONTEIRO (nota 3 acima) 
similar à distinção entre serviços de telecomunicações prestados em regime público e em regime privado, consagrada na Lei $\mathrm{n}^{\mathbf{0}}$ 9.472/97).

A competência para a disciplina do setor de limpeza urbana é atribuída constitucionalmente aos municípios (art. 30, V, da Constituição Federal). Deve-se observar, porém, que as questões relacionadas com saneamento básico e proteção ambiental são objeto de competência comum da União, dos Estados, do Distrito Federal e dos Municípios (art. 23, VI e IX, da Constituição Federal) e que a proteção do meio ambiente e o controle da poluição são matérias de competência concorrente (art. 24, VI, da Constituição Federal). O estabelecimento de normas gerais acerca da regulação do setor de limpeza urbana pode ser feito (a depender da abrangência de tais normas gerais) mediante lei complementar federal (art. 23, parágrafo único, da Constituição) ou através de lei ordinária federal (art. $24, \S \S 1^{\circ}$ a $4^{\ell}$, da Constituição). A ausência de normas gerais estabelecidas por lei federal não suprime nem reduz a competência plena dos municípios para o regramento da área de limpeza urbana.

18. Não há, porém, notícia de qualquer iniciativa legal nesse sentido até o momento.

A concessão de serviços de limpeza urbana no Brasil tem sido configurada sob a premissa de que todas as atividades de limpeza urbana têm caráter público e são de titularidade do município - que as pode realizar diretamente ou conceder total ou parcialmente (ainda que de modo subsidiário em relação a parte dessas atividades).

Já se apontou, nos itens anteriores, que essa configuração admite completa alteração, com a adoção de solução mais consentânea com a evolução do papel do Estado. Essa solução é admitida e recomendada pelo ordenamento constitucional brasileiro - embora sua aplicação venha sendo importante mas desordenada na área de limpeza urbana.

19. Desse modo, o presente estudo pretende enfrentar algumas das questões concretamente levantadas em relação à concessão de serviços de limpeza urbana, tal como configurada atualmente no Brasil.

Os problemas a serem examinados são os seguintes:

a) competência para a outorga da concessão no caso de serviços transmunicipais;

b) especificidade e divisibilidade dos serviços de limpeza urbana;

c) natureza jurídica (taxa ou tarifa) dos valores cobrados pela concessionária dos usuários dos serviços;

d) problemas derivados do inadimplemento dos usuários.

\section{VI - Competência administrativa no caso de serviços transmunicipais}

20. Os serviços de limpeza urbana podem assumir, por razões técnicas ou econômicas, configuração que ultrapassa os limites do território de um município.

É o caso, por exemplo, da construção de aterro sanitário, incinerador, esterilizador ou de usina de compostagem ou separação de material reciclado em um município, com a previsão de processamento de resíduos captados em diversos outros. É também o que ocorre na hipótese de ser economicamente inviável a atuação 
do setor privado em um município, tornando-se viável a atuação, na medida em que os serviços se estendam a população mais numerosa de municípios vizinhos.

Nesses casos, os serviços de limpeza urbana passam a assumir caráter transmunicipal. Pressupõem uma conjugação de interesses de vários municípios, seja para a sua prestação direta, seja para a outorga do seu exercício a entidade privada.

Marçal Justen Filho examinou o tema a respeito dos serviços de abastecimento de água que afetassem mais de um município, apontando que a solução tradicional (concessão outorgada a entidade da administração indireta estadual) configurava concessão imprópria, que ocultava verdadeiro convênio entre os entes públicos ${ }^{34}$. A conclusão partia de premissa aplicável ao presente estudo, segundo a qual "Respeitados os princípios fundamentais norteadores do sistema jurídico, a existência dos convênios decorre do postulado de que a competência é outorgada a diversos sujeitos políticos autônomos, mas para a realização de um único interesse público. Na sua pluralidade, esses entes podem (devem) atuar conjugada e harmonicamente para multiplicação de esforços e realização mais eficiente dos interesses comuns" 35. Também em relação a municípios envolvidos em serviços de limpeza urbana, a atuação mediante convênio pode ser a única via adequada para o atendimento dos interesses coletivos envolvidos nesses serviços.

Em estudo de 1997, Floriano Azevedo Marques Neto concluiu ser viável a um conjunto de municípios, reunidos em consórcio, promover licitação e outorga de contrato de concessão de serviço de limpeza urbana, desde que mediante autorização legislativa e observados os trâmites normais do procedimento licitatório para a concessão (inclusive quanto à sua fase interna) ${ }^{36}$.

21. Embora possam afetar, por razões técnicas ou econômicas, mais de um município, os serviços de limpeza urbana referem-se fundamentalmente a interesses peculiares de cada município. Não estão excluídos, portanto, da competência do art. 30, V, da Constituição Federal. Cada município detém competência exclusiva para dispor acerca da limpeza urbana no âmbito de seu território.

Essa outorga de competência abrange a competência para, em acordo com outros municípios, disciplinar os reflexos de tais serviços que possam ultrapassar os limites do território. Não haveria sentido, por exemplo, em que cada município fosse constrangido a construir e manter a infra-estrutura necessária para a prestação dos serviços de limpeza urbana - na medida em que pudesse compartilhar a infra-estrutura construída mediante convênio com os municípios vizinhos.

Nessa situação, o convênio (celebrado mediante autorização legislativa) deverá disciplinar relacionamento complexo. Ainda que a execução do serviço não se faça mediante concessão, haverá dificuldades a superar quanto ao exercício das funções de autoridade no controle da execução dos serviços ou quanto ao domínio das obras de infra-estrutura, por exemplo.

34 Ob. cit., p. 76.

35 Ob. cit., p. 75.

36 Outorga de Concessão de Serviços de Limpeza Urbana por Consórcio Intermunicipal, em Boletim de Direito Administrativo. v. 13, n 10, pp. 681/687. outubro de 1997. 
Na hipótese de exploração do serviço através de concessão. as dificuldades serão ainda mais intensas. O compartilhamento das funções de poder concedente dificilmente poderá ser disciplinado de forma adequada no convênio. A reversão dos bens ao término da concessão consistirá em outro problema de difícil solução.

A Emenda Constitucional $\mathrm{n}^{\mathrm{0}} 19$, de 4 de junho de 1998, produziu alteração relevante para o tema aqui examinado. A nova redação do art. 24 da Constituição Federal define que "A União, os Estados, o Distrito Federal e os Municípios disciplinarão por meio de lei os consórcios públicos e os convênios de cooperação entre os entes federados, autorizando a gestão associada de serviços públicos, bem como a transferência total ou parcial de encargos, serviços, pessoal e bens essenciais à continuidade dos serviços transferidos."

Ao aludir a consórcios públicos e convênios de cooperação, a Constituição previu instrumentos para a conjugação de esforços na realização de serviços públicos. Não há nenhuma indicação de que a regra seja inaplicável a concessões. As regras acerca da autonomia municipal devem ser interpretadas de modo a possibilitar que, autorizado por lei, o município integre consórcios ou celebre convênios para o exercício compartilhado do poder concedente.

Pode-se cogitar, ainda, de solução destinada a reduzir as dificuldades políticas na obtenção de um consórcio ou um convênio em termos aceitáveis para o conjunto de municípios. Seria o caso da celebração de convênio com a previsão de que cada um dos municípios envolvidos devesse conceder serviços relacionados com determinada fase do processo de remoção e destinação de lixo. Assim, um dos municípios concederia os serviços de coleta e processamento do lixo em aterro sanitário e usina de compostagem e os demais concederiam apenas o serviço de coleta, com a previsão de entrega dos resíduos para processamento no aterro e na usina situados no município vizinho (mediante pagamento de tarifa ao operador desses equipamentos de infra-estrutura).

Não seria desarrazoado que, diante dos elevados investimentos de infra-estrutura necessários à adoção de técnicas mais modernas de processamento de lixo, essa matéria fosse disciplinada através de agência reguladora no âmbito de cada estado federado. À agência caberia a organização dos serviços de limpeza urbana, definindo a localização de equipamentos de infra-estrutura necessários ao atendimento dos vários municípios.

Outra possibilidade de solução do problema consistiria na definição dos conjuntos de municípios como região metropolitana, aglomeração urbana ou microrregião. Nesse caso, a competência para a concessão dos serviços poderia ser estabelecida na forma do art. $25, \S 3^{\mathrm{o}}$, da Constituição Federal, através de lei complementar estadual. Seria cogitável que a lei complementar estadual definisse as regiões e disciplinasse o desempenho conjunto pelos municípios de certos serviços relativos à limpeza urbana (inclusive, também neste caso, através de uma agência reguladora estadual).

\section{VI - Possibilidade de identificação do usuário como requisito da concessão}

22. Maria Sylvia Zanella di Pietro aponta que somente pode haver concessão ou permissão de serviços públicos “...quando se tratar de serviço prestado a tercei- 
ros (usuários) e que admita uma exploração comercial, ou seja, a possibilidade de renda em favor do concessionário" ${ }^{37}$. Em sentido similar, Marçal Justen Filho anota que a concessão é caracterizada por o concessionário "não receber remuneração direta da Administração Pública" : o concessionário "remunera-se através da cobrança de tarifas dos usuários" ${ }^{38}$ — além da percepção de outras receitas acessórias que se integram no equilíbrio econômico-financeiro do contrato ${ }^{39}$.

O montante cobrado pelo concessionário dos usuários do serviço não se confunde com taxa pela prestação de serviço público (art. 145, II, da Constituição Federal). Esse ponto será objeto de discussão em tópico seguinte.

Os requisitos de especificidade e de divisibilidade previstos no art. 145, II, da Constituição em relação às taxas não se aplicam às tarifas com o rigor do direito tributário. Há a necessidade de se identificar um usuário para os serviços concedidos, de forma a evitar cobranças arbitrárias. Até certo ponto, são aplicáveis os raciocínios construídos pelo direito tributário sobre a especificidade e a divisibilidade dos serviços (mesmo porque, no próprio direito tributário, a definição do critério de repartição dos custos dos serviços baseia-se em presunções e aproximações). Porém, a ausência de especificidade ou de divisibilidade, segundo parâmetros de direito tributário, pode não ser impedimento à concessão dos serviços nem à fixação de tarifas para sua remuneração.

É relevante, assim, examinar a atual concepção de tais requisitos em relação aos serviços de limpeza urbana. Como é peculiar da concessão que a remuneração do concessionário se faça através de pagamentos realizados pelos usuários, é necessário determinar quem são os usuários e em que medida cada usuário recebe os serviços prestados pelo concessionário - ainda que sem o rigor de que essa determinação se reveste no direito tributário.

Esses dados correspondem, em linhas gerais, aos conceitos de especificidade e divisibilidade consagrados no art. 145, II, da Constituição Federal. Não se trata, porém, dos mesmos conceitos. O regime de direito tributário é mais rigoroso que o aplicável à concessão de serviços públicos. Como já se apontou, a eventual ausência de especificidade ou divisibilidade, segundo os critérios de direito tributário, pode não ser determinante da impossibilidade de concessão dos serviços.

Somente podem ser objeto de concessão serviços públicos passíveis de utilização por pessoas determinadas. Não haveria sentido (nem validade) na concessão de serviço público de serviço prestado indistintamente a toda a coletividade, sem que se pudessem identificar seus usuários e as medidas aproximadas do uso. $O$ defeito estaria em que, nessa situação, ou não poderia haver a cobrança de remuneração junto a usuários ou a cobrança seria arbitrária. Em qualquer dos casos, a concessão seria inválida.

37 Parcerias na Administração Pública, Atlas. 1996. p. 45.

38 Concessōes... p. 67

39 JUSTEN FILHO, MARÇAL. Concessöes... pp. 158 e seguintes. 
23. Ao examinar a taxa de limpeza urbana, a jurisprudência do Superior Tribunal de Justiça vinha afirmando, até 1997, a presença dos requisitos de especificidade e divisibilidade.

Em muitos casos, era destacada a distinção entre a taxa de iluminação pública e a taxa de limpeza urbana. Nesse passo, a $1^{\underline{a}}$ Turma do Superior Tribunal de Justiça assentou que "Conforme orientação desta Colenda Turma, nos serviços públicos referentes à conservação e limpeza de vias públicas encontram-se presentes os requisitos de especificidade e da divisibilidade, previstos no CTN (arts. 77 e 79), o que não ocorre com o serviço de iluminação pública, que tem caráter genérico e não divisível, sendo prestado à coletividade como um todo ${ }^{40}$.

Em dezembro de 1996, o Tribunal Pleno do Supremo Tribunal Federal examinou o Recurso Extraordinário $\mathrm{n}^{\mathrm{Q}} 204.827$, relativo às Leis $\mathrm{n}^{\mathrm{Q}} 6.989 / 66$ e 11.152/91 do Município de São Paulo, inclusive quanto às taxas de limpeza pública e de conservação de vias e logradouros públicos. A ementa do acórdão foi a seguinte:

“TRIBUTÁRIO. LEI No 11.152, DE 30 DE DEZEMBRO DE 1991, QUE DEU NOVA REDAÇÃO AOS ARTS. 70, INCS. I E II; 87, INCS. I E II; E 94, DA LEI NQ 6.989/66, DO MUNICÍPIO DE SÃO PAULO. IMPOSTO SOBRE A PROPRIEDADE PREDIAL E TERRITORIAL URBANA. TAXAS DE LIMPEZA PÚBLICA E DE CONSERVAÇÃO DE VIAS E LOGRADOUROS PÚBLICOS.

"Insconstitucionalidade dos dispositivos sob enfoque. O primeiro, por instituir aliquotas progressivas alusivas ao IPTU, em razão do valor do imóvel, com ofensa ao art. 182, $\S 4^{\underline{0}}$, II, da Constituição Federal, que limita a faculdade contida no art. $156, \S I^{0}$, à observância do disposto em lei federal e à utilização do fator tempo para a graduação do tributo.

"Os demais, por haverem violado a norma do art. $145, \S 2^{Q}$, ao tomarem para base de cálculo das taxas de limpeza e conservação de ruas elemento que o STF tem por fator componente da base de cálculo do IPTU, qual seja, a área do imóvel e a extensão deste no seu limite com o logradouro público.

"Taxas que, de qualquer modo, no entendimento deste Relator, têm por fato gerador prestação de serviço inespecífico, não mensurável, indivisível e insuscetível de ser referido a determinado contribuinte, nāo sendo de ser custeado senão por meio do produto da arrecadação dos impostos gerais. Não conhecimento do recurso da Municipalidade.

"Conhecimento e provimento do recurso do contribuinte". 41

O precedente do Supremo Tribunal Federal provocou a alteração do entendimento do Superior Tribunal de Justiça sobre o tema. Ambas as Turmas competentes do Superior Tribunal de Justiça adotavam orientação predominante acerca da validade da taxa de limpeza pública. Após o julgamento do Supremo Tribunal Federal,

40 R. Esp. 87.851/RJ, I ${ }^{\mathrm{a}}$ T., Rel. Min. José de Jesus Filho, j. 13.12.96, publ. DJU 17.3.97, p. 7.434. No mesmo sentido, R. Esp. 113.757/RJ, 1ํㅗㄹ T., Rel. Min. José Delgado. j. 7.4.97, publ. DJU 19.5.97, p. 20.593. 41 RE no 204.827/SP. Pleno, Rel. Min. Ilmar Galvão, j. 12.12.96, maioria, publ. DJU 25.4.97, p. 15.213. No mesmo sentido, RE no 199.969/SP, Pleno. Rel. Min. Ilmar Galvão, j. 27.11.97, maioria, publ. DJU 6.2 .98 , p. 38 . 
o entendimento foi alterado no âmbito das Turmas e, em dezembro de 1997 , a $1^{\text {a }}$ Seção do Superior Tribunal de Justiça uniformizou o seu entendimento de modo consistente com a orientação do Supremo Tribunal Federal (alterando o entendimento firmado pela própria $1^{a}$ Seção em fevereiro de 1997), em acórdão assim ementado:

“TRIBUTÁRIO. TAXA DE LIMPEZA URBANA, MUNICÍPIO DE SÃO PAULO.

1. Lei $6.989 / 1966$, modificada pela Lei de $\mathrm{n}^{\mathrm{o}} 10.921 / 1990$, arts. $7^{\mathrm{o}}, 87$, incs. I e II, e art. 94. Inconstitucionalidade reconhecida, por maioria, pelo Colendo Supremo Tribunal Federal ao julgar, pelo Pleno, em data de 17.12.97, o Recurso Extraordinário 204827-SP, acórdão publicado no DJU de 25.04.97, relatado pelo Eminente Ministro Ilmar Galvão, onde a referida taxa foi examinada, cuja ementa do acórdão está assim expressa: 'TRIBUTÁRIO. LEI N¹1.152, DE 30 DE DEZEMBRO DE 1991, QUE DEU NOVA REDAÇĀO AOS ARTS. 70, INCS. I E II; 87, INCS. I E II, E 94, DA LEI No 6.989/66, DO MUNICÍPIO DE SÃO PAULO. IMPOSTO SOBRE A PROPRIEDADE PREDIAL E TERRITORIAL URBANA. TAXAS DE LIMPEZA PÚBLICA E DE CONSERVAÇÃO DE VIAS E LOGRADOUROS PÚBLICOS. Inconstitucionalidade dos dispositivos sob enfoque. $O$ primeiro, por instituir alíquotas progressivas alusivas ao IPTU, em razão do valor do imóvel, com ofensa ao art. 182, $\S 4^{q}, I I$, da Constituição Federal, que limita a faculdade contida no art. $156, \S 1^{2}$, à observância do disposto em lei federal e à utilização do fator tempo para a graduação do tributo. Os demais, por haverem violado a norma do art. $145, \S 2$, ao tomarem para base de cálculo das taxas de limpeza e conservação de ruas elemento que o STF tem por fator componente da base de cálculo do IPTU, qual seja, a área do imóvel e a extensão deste no seu limite com o logradouro público. Taxas que, de qualquer modo, no entendimento deste Relator, têm por fato gerador prestação de serviço inespecífico, não mensurável, indivisivel e insuscetivel de ser referido a determinado contribuinte, não sendo de ser custeado senão por meio do produto da arrecadação dos impostos gerais. Não conhecimento do recurso da Municipalidade. Conhecimento e provimento do recurso do contribuinte'.

"2. A declaração de inconstitucionalidade, embora 'incidenter tantum' dos referidos dispositivos legais, afeta o exame da legalidade ou da ilegalidade dos dispositivos supra em sede de recurso especial.

“3. Face essa orientação firmada pelo C. Supremo Tribunal Federal, não prevalece entendimento fixado pela $1^{a}$ Seção do Superior Tribunal de Justiça, em data de 26.02.1997, ao apreciar os embargos de divergência no Recurso Especial 35.158, de São Paulo, da relatoria do Eminente Ministro Demócrito Reinaldo, acórdão publicado no DJU de 24.03.1997, p. 8.966, por unanimidade, cujos termos são revelados na ementa seguinte: 'PROCESSUAL CIVIL E TRIBUTÁRIO. EMBARGOS DE DIVERGÊNCIA. TAXAS DE LIMPEZA URBANA E DE CONSERVAÇÃO DE VIAS E LOGRADOUROS PÚBLICOS. I - Nos serviços públicos relativos a limpeza urbana e conservação de vias e logradouros públicos, encontram-se presentes os requisitos de especificidade e de divisibilidade (arts. 77 e 79 do CTN). II - As taxas de consumação desses serviços têm como fato gerador 'o exercício do poder de polícia, a utilização efetiva ou potencial do serviço público específico e divisível, prestado ao contribuinte ou posto à sua disposição'. III - Embargos de divergência recebidos, sem discrepância'. 
“4. Diante desse quadro jurisprudencial, não há de se acolher os embargos de divergência apresentados pelo Estado de São Paulo, para fazer prevalecer o entendimento e conclusão desenvolvidos no acórdão embargado (R. Esp. 35.158-0/SP, Rel. Min. Ari Pargendler, Segunda Turma, unânime, DJ 12/08/96), por se apresentarem em harmonia com a posição do C. Supremo Tribunal Federal.

"5. Embargos rejeitados para os fins acima determinados" 42 .

O entendimento do Superior Tribunal de Justiça sobre a matéria foi traduzido em outro julgamento realizado na mesma data pela $1^{\mathbf{a}}$ Seção e é retratado na ementa adiante transcrita:

“TRIBUTÁRIO. TAXA DE LIMPEZA URBANA. LEI No 6.989, DE 1966, NA REDAÇÃO DADA PELA LEI 11.152, DE 1991, DO MUNICÍPIO DE SÃO PAULO.

"A taxa de limpeza urbana, no modo como disciplinada no Município de São Paulo, remunera - além dos serviços de 'remoção de lixo domiciliar' - outros que não aproveitam especificamente ao contribuinte ('varriçäo, lavagem e capinação'; 'desentupimento de bueiros e bocas-de-lobo'); ademais, a respectiva base de cálculo não está vinculada à atuação estatal, valorizando fatos incapazes de mensurar-lhe o custo (localização, utilização e metragem do imóvel) - tudo com afronta aos arts. 77, caput, e 79, inc. II, do CTN.

"Embargos de divergência acolhidos" 43.

26. A orientação do Supremo Tribunal Federal acerca da especificidade e divisibilidade dos serviços de limpeza urbana (para o fim de instituição de taxas, já que o tema não foi examinado quanto a tarifas por serviços concedidos de limpeza urbana) ainda não é clara. O tema foi ventilado no precedente acima transcrito apenas como opinião pessoal do Min. Ilmar Galvão - embora o único voto contrário no julgamento do Pleno tenha sido o do Min. Carlos Mário Velloso. O fundamento central para o reconhecimento, por maioria, da invalidade da taxa consistiu na suposta adoção de base de cálculo típica de imposto (IPTU) ${ }^{44}$.

É mais nítida a orientação do Superior Tribunal de Justiça. A lei municipal de São Paulo foi reprovada por incluir, como serviços ensejadores da taxa de limpeza pública, atividades não diretamente relacionadas com os usuários. A ausência de especificidade não estava necessariamente no serviço de recolhimento de lixo (ou mesmo nos serviços relacionados com a destinação do lixo), mas na varrição e

42 STJ, 1² Seção, ERESP 94.314/SP, Rel. Min. José Delgado, j. 16.12.97, unânime, publ. DJU 6.4.98, p. 8.

43 STJ, $1^{2}$ Seção, ERESP 102.404/SP, Rel. Min. Ari Pargendler, j. 16.12.97, unânime, publ. DJU 2.2.98, p. 36.

44 O julgamento do STF foi reiterado no Recurso Extraordinário n 199.969-1/SP, também relatado pelo Min. Ilmar Galvão. Desse julgamento participaram, acompanhando o relator sem declaraçāo de voto, os Min. Moreira Alves, Néri da Silveira, Sydney Sanches, Octávio Gallotti, Sepúlveda Pertence, Marco Aurélio e Maurício Corrêa. O único voto divergente foi o do Min. Carlos Mário Velloso. Do voto do Min. Ilmar Galvão, colhe-se que "trata-se de atividade estatal de caráter uti universi, destinada ao benefício da população em geral. não podendo tais prestações de serviço ser destacadas em unidades autônomas, nem permitindo a individualização sua área de intervenção, além de não se apresentarem suscetíveis de utilização separada. por parte de cada um de seus usuários" (Revista Dialética de Direito Tributário n을 31 p. 181). 
remoção de resíduos dos logradouros públicos e na limpeza de bueiros e bocas-delobo.

Parece-nos que o mesmo problema poderia ocorrer com o serviço de remoção de resíduos produzidos por estabelecimentos de saúde, caso a tarifa não fosse paga pelo próprio estabelecimento de saúde mas pela generalidade dos cidadãos (sob o pressuposto de que o serviço de remoção de tais resíduos atenderia a uma necessidade de interesse coletivo). A concessão de tais serviços deve prever a sua remuneração através de tarifas específicas para os estabelecimentos geradores dos resíduos.

Tal como quase unanimemente reconhecido pela jurisprudência ${ }^{45}$, os serviços de iluminação pública não apresentam especificidade nem divisibilidade. A orientação jurisprudencial quanto aos serviços de remoção e destinação de resíduos encontrados nos logradouros públicos tende a ser a mesma - o que já se retrata na orientação predominante do Supremo Tribunal Federal e do Superior Tribunal de Justiça. Trata-se, não se discute, de serviços de interesse coletivo. Isso os qualifica (desde que mediante previsão normativa) como serviços públicos mas não os torna necessariamente específicos nem divisíveis. Não é possível estabelecer uma presunção de que todos os cidadãos são igualmente beneficiados pelos serviços que atendam à coletividade, porque esse raciocínio esvazia o conceito de serviço específico e divisível adotado de modo expresso na Constituição Federal. Tais serviços não seriam especificamente dirigidos a usuários identificáveis.

É relevante perceber, porém, que essa orientação jurisprudencial (posterior a 1997, como se apontou) baseia-se em precedente relacionado com lei municipal que elegera como critério de repartição do custo do serviço a área ou a testada de cada imóvel existente no território do município. Assim, o fundamento para a decretação da invalidade da lei municipal que instituiu a taxa de limpeza urbana pode ter sido antes a escolha inadequada de um critério de identificação do usuário e de medição do serviço utilizado que a impossibilidade técnica de existir critério apropriado para esses fins.

Isso pode significar que poderia ser outra a definição do problema na medida em que os critérios para a medição da quantidade de serviço utilizada pelos vários indivíduos fossem mais adequados e complexos.

Os avanços tecnológicos permitem o processamento rápido de um grande número de informações. Possibilitam ao Poder Público aproximar-se, através de dados estatísticos, da realidade individual de cada cidadão. É possível a apuração de dados estatísticos que permitam definir, com razoável aproximação, critérios de medição da utilização de serviços de limpeza pública (tanto os de coleta individual quanto os de remoção e destinação de resíduos de logradouros públicos).

A definição do montante individual da tarifa (o que pressupõe a viabilidade de identificação de um usuário individual) é informada por um princípio de praticabilidade. Deve haver composição equilibrada entre a certeza quanto à identificação do usuário e a medição da quantidade de serviço utilizada e a necessidade da cobrança 
da tarifa. Esses fatores devem ser combinados de forma que nem a certeza nem a necessidade sejam integralmente sacrificadas. Devem-se adotar presunções construídas sobre indícios relevantes, de forma a simplificar e tornar mais razoável a instituição da tarifa.

Note-se que a cobrança de tarifa (ou da taxa) como contrapartida pela prestação de serviço público realiza o princípio da isonomia, já que exige de quem utiliza certo serviço que remunere o seu prestador. Ou seja, paga apenas quem utiliza o serviço. Considerar impossível a cobrança de taxa ou tarifa impede a adoção dessa forma de remuneração e faz com que os serviços que beneficiam mais intensamente certas pessoas sejam custeados pela coletividade.

É possível, portanto, a concepção de critério tecnicamente adequado para a identificação dos usuários do serviço e para a medição do grau de utilização de cada usuário. Esse critério pode ser aproximativo e baseado em presunçōes, de modo a preservar a praticabilidade na outorga da concessão dos serviços e na fixação das tarifas correspondentes.

\section{VIII - Natureza das cobranças do concessionário}

27. Já se apontou ser do núcleo da concessão a ausência de remuneração pelo Poder Público (com raras e específicas exceções) e a percepção, pelo concessionário, de remuneração paga pelo próprio usuário do serviço.

A garantia de remuneração mínima pelo Poder Público (através, por exemplo, de pagamentos que eliminassem ou reduzissem os riscos do concessionário) é proibida diante do veto presidencial ao art. 24 da Lei n 8.987/95. Segundo Marçal Justen Filho, "o art. 24 facultava fixar-se receita bruta mínima em favor do concessionário, reduzindo radicalmente o risco do empreendimento. $O$ dispositivo foi vetado, inclusive sob o fundamento de incentivar-se a ineficiência operacional e risco de dispêndios para o poder concedente" ${ }^{46}$. O concessionário deve assumir os riscos do empreendimento relacionado com a concessão.

Não é vedada a percepção de receitas acessórias (aliás, previstas expressamente no art. 11 da Lei $n^{2} 8.987 / 95$ ). No caso das concessões de serviços de limpeza urbana, são cogitáveis receitas acessórias derivadas de publicidade (nos veículos e nas latas de lixo) e da venda de compostos orgânicos ou de produtos para reciclagem, por exemplo.

A receita principal do concessionário, porém, será usualmente (mas não necessariamente) o recebimento da remuneração paga pelo usuário - que poderá ser o cidadão particular, no caso de remoção de resíduos domiciliares, ou outros eventuais operadores do serviço de coleta e destinação dos resíduos (no caso de concessão específica para a exploração de aterros sanitários, incineradores ou de usinas de compostagem).

46 Concessões... p. 110. 
28. Deve-se determinar se a cobrança realizada pelo concessionário ao usuário dos serviços consiste em taxa (submetida ao regime de direito tributário) ou tarifa (submetida ao regime de direito administrativo).

Já se expôs que, no caso das atividades competitivas envolvidas nos serviços de limpeza urbana, a cobrança não deve ser nem taxa nem tarifa, mas mero preço de direito privado, fixado com liberdade pelo prestador do serviço. O tratamento dos serviços de limpeza pública no Brasil deve evoluir para que se atinja esse grau de liberdade nas atividades não necessariamente submetidas ao regime público. Essa situação já ocorre em diversos dos serviços relacionados com a limpeza urbana, prestados atualmente por empresas privadas sem prévia concessão de serviço público.

$\mathrm{Na}$ situação atual, com a definição, pelas legislações municipais, do serviço de limpeza urbana como de natureza pública em termos amplos e genéricos, a definição da natureza da cobrança deve ser examinada a partir da distinção entre taxa e tarifa.

30. As diferenças de regime jurídico são relevantes.

30.1. As taxas são figuras de direito tributário. Submetem-se ao regime tributário, especialmente ao princípio da legalidade e da anterioridade. Desse modo, somente podem ser instituídas ou majoradas mediante lei publicada no exercício financeiro anterior àquele em que deva incidir.

As consequiências do regime tributário, porém, não são apenas essas. Com base no art. 145, II, da Constituição Federal, é possível a instituição de taxa vinculada a serviço público fruível, não efetivamente fruído mas posto à disposição do usuário — desde que o serviço seja de utilização compulsória. É o caso do serviço de coleta, tratamento e destinação final dos resíduos domésticos. A ninguém é dado recusar-se a receber o serviço de remoção e destinação de lixo - mantendo-o, por exemplo, armazenado em depósito particular. $O$ interesse protegido pelo serviço transcende o do particular; protege-se o interesse coletivo traduzido na saúde pública. $O$ particular é legalmente obrigado a utilizar os serviços de coleta e destinação de lixo, assim como o Poder Público municipal é obrigado a prestá-lo (diretamente ou mediante concessão ou permissão).

Além disso, as taxas inserem-se no quadro mais amplo da tributação como manifestação de solidariedade social. $\mathrm{O}$ art. $3^{0}$, I, da Constituição Federal consagra o objetivo fundamental de construção de uma sociedade livre, justa e solidária. A solidariedade se traduz no direito tributário através da entrega ao Estado de parte do próprio patrimônio sem a expectativa de contrapartida. Em relação às taxas de serviço, o princípio da isonomia conduziria a uma aplicação rigorosa da noção de retribuição - - de forma que cada particular beneficiado pela atuação do Estado pagasse taxa no valor correspondente a essa atuação. O princípio da solidariedade tempera essa aplicação rigorosa da isonomia, dando fundamento às isenções e reduções reservadas aos usuários de menor capacidade econômica (distribuindo-se os encargos correspondentes à coletividade, através de seu custeio com a receita de impostos).

Sob o ângulo da cobrança, as taxas submetem-se às regras de direito administrativo tributário. São passíveis de inscrição em dívida ativa e ensejam a cobrança judicial mediante execução fiscal. 
A situação não se alteraria em face de a cobrança ser promovida por ente particular (o concessionário dos serviços que ensejam a taxa). Tratar-se-ia de mera situação de parafiscalidade. em que se atribui ao particular a capacidade tributária ativa sem se modificar a natureza jurídica da cobrança. Ou seja: é possível à lei atribuir ao ente particular (concessionário dos serviços) a capacidade para exigir o pagamento da taxa e para administrar o produto de sua arrecadação.

30.2. As tarifas, de outro lado, não são tributos.

São fixadas mediante atos administrativos (portanto infralegais) e se relacionam especificamente com a remuneração de serviços públicos prestados por entes não integrantes da Administração direta. Não são livremente estipuladas, mas seguem os princípios e parâmetros comuns da atuação administrativa (inclusive quanto à sua subordinação à lei). Não se submetem, porém, ao princípio da anterioridade, de conteúdo estritamente tributário.

Não há a previsão constitucional de cobrança de tarifas por serviços não efetivamente fruídos (ou seja, apenas postos à disposição dos usuários). A cobrança de valores mínimos pela mera disponibilização dos serviços depende da previsão legal dos critérios para a verificação do que significam os serviços mínimos postos à disposição de todos e da compulsoriedade de utilização dos serviços.

O princípio da solidariedade social é princípio constitucional geral. Não é aplicável apenas ao direito tributário. Porém, sua aplicação em relação às tarifas produz consequiências diversas das que se verificam quanto às taxas. Havendo a consagração de isenções, tarifas reduzidas ou tarifas sociais, o custo correspondente à redução ou é suportado pelo próprio concessionário ou é repartido entre os demais usuários (mediante uma elevação da tarifa) - uma vez que o concessionário não dispõe, ao contrário do Poder Público no caso das taxas, da receita de impostos para enfrentar esses custos. A segunda situação é ofensiva ao princípio da isonomia, já que o custo da solidariedade deve ser imputado a toda a coletividade, não apenas aos demais usuários do serviço. Resta a primeira situação, que é válida na medida em que consagrada claramente nas condições da concessão. Caso contrário, caberá ao Poder Público ressarcir o concessionário do custo da subvenção das tarifas reduzidas ou sociais ${ }^{47}$.

Note-se que, no caso específico das tarifas de limpeza urbana, pode haver uma coincidência entre os destinatários da cobrança das tarifas (habitantes de certa cidade) e os integrantes da coletividade afetada pelo dever de solidariedade. Nesse caso, é possível que a solidariedade social que conduz à adoção de tarifas sociais traduza-se na elevação da tarifa dos demais usuários do serviço (entre os quais seria distribuído o custo da subvenção das tarifas sociais).

A cobrança das tarifas se faz segundo as regras aplicáveis aos créditos em geral, sem os privilégios das cobranças tributárias. Em geral, a tarifa não virá instrumentalizada em título executivo. Sua cobrança dependerá de condenação em processo de conhecimento.

47 No mesmo sentido. MARÇAL JUSTEN FILHO afirma que, diante das várias dificuldades envolvidas nesse tema. a solução "é o Estado custear essas tarifas sociais" (Concessōes... p. 164). 
31. A discriminação entre taxa e tarifa gerou, no âmbito do Supremo Tribunal Federal, a edição da Súmula $\mathrm{n}^{\circ}$ 545, com o seguinte teor: "Preços de serviços públicos e taxas não se confundem, porque estas, diferentemente daquelas, são compulsórias e têm sua cobrança condicionada à prévia autorização orçamentária, em relação à lei que as instituiu."

A referência à compulsoriedade não se vincula ao dever de pagar, já que ambos (tarifa e taxa) são objeto de um dever jurídico. Relaciona-se com a utilização do serviço. Os serviços de utilização compulsória seriam sempre objeto de taxa; os serviços de utilização não compulsória poderiam ser objeto de tarifa (quando prestados por entes não integrantes da Administração direta) ou taxa (quando prestados diretamente pelo Estado).

O critério não vem sendo aplicado com rigor. Segundo Marçal Justen Filho, " $a$ jurisprudência não segue orientação definida no campo da diferenciação entre taxa à tarifa. Muitos julgadas continuam aplicando o entendimento constante da Súmula 545 do STF. As dúvidas ficaram muito evidentes nas disputas acerca da natureza jurídica do Adicional de Tarifa Portuária (ATP), tema que foi objeto de inúmeras decisões contraditórias entre si. Há forte tendência a continuar a aplicar o instituto da taxa para serviços públicos específicos e divisíveis, cujo consumo seja compulsório para o usuário" ${ }^{48}$.

O doutrinador menciona importante precedente do Supremo Tribunal Federal, proferido em 4 de setembro de 1980 no Recurso Extraordinário $n^{2} 89.876 / \mathrm{RJ}$, atinente a tarifa de limpeza urbana cobrada pela companhia de limpeza urbana do Rio de Janeiro. Da ementa do acórdão colhe-se o seguinte: "Tarifa básica de limpeza urbana. Em face das restrições constitucionais a que se sujeita a instituição de taxa, não pode o Poder Público estabelecer, a seu arbítrio, que à prestação de serviço público específico e divisivel corresponde contrapartida sob a forma, indiferentemente, de taxa ou de preço público. Sendo compulsória a utilização do serviço público de remoção de lixo - o que resulta, inclusive, de sua disciplina como serviço essencial à saúde pública -, a tarifa de lixo instituida pelo Dec. 196, de 12.11.75, do Poder Executivo do Município do Rio de Janeiro, é, em verdade, taxa" ${ }^{49}$.

A orientação do Supremo Tribunal Federal baseava-se em dispositivo correspondente ao atual art. 145, II, da Constituição Federal. Na medida em que a regra constitucional vinculava a prestação de serviços públicos específicos e divisíveis à cobrança de taxa, não se reputou possível que se vinculasse a essa mesma categoria de serviços cobrança de outra natureza.

Porém, o raciocínio exige temperamentos a partir da consagração, pela Constituição Federal, da regra constante do art. 175 (que já constava, na essência, da Constituição Federal anterior). $O$ dispositivo prevê a possibilidade de a prestação de

48 Concessões... p. 145.

49 Pleno, Rel. min. Moreira Alves, j. 4.9.80, publ. DJU 10.10.80, em RTJ 98/230. No mesmo sentido, as duas Turmas do STF proferiram decisões unânimes no RE 89.049/RJ ( $2^{\mathrm{a}} \mathrm{T}$., Rel. Min. Leitão de Abreu,

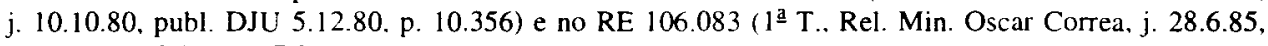
publ. DJ 4.10.85, p. 17.210). 
serviços públicos ser feita mediante a participação de particulares na condição de concessionários ou permissionários do serviço público. Segundo Marçal Justen Filho, "A concessão do serviço público produz, portanto, inovações no regime jurídico aplicável. Passa-se a considerar cabivel o dado da lucratividade - o que é inconcebivel na atividade administrativa desempenhada pelo Estado. O particular tem assegurado o direito à manutenção do equilíbrio econômico-financeiro inicial. Enfim, o insucesso será arcado pelo particular" ${ }^{50}$.

De acordo com o doutrinador, esse regime pressupõe a possibilidade de alteração de tarifa a qualquer tempo, como instrumento para a manutenção do equilíbrio econômico-financeiro. Por isso, conclui que "o regime tributário é incompativel com o regime jurídico da remuneração do concessionário (permissionário). Quando o Estado outorga concessão, não se altera o regime jurídico da prestação do serviço público, mas se modifica o regime jurídico de sua remuneração. A Constituição Federal, ao tutelar a intangibilidade da equação econômico-financeira do contrato administrativo, produz uma espécie de redução da amplitude eficacial do sistema tributário. Retira do seu âmbito a remuneração atinente aos serviços públicos outorgados aos particulares por via de concessão ou permissão". ${ }^{51}$

$\mathrm{O}$ art. 175 da Constituição (ao consagrar a concessão de serviços públicos) e o art. 37, XXI, da Constituição (ao proteger a equação econômico-financeira dos contratos de concessão) excepcionam o art. 145, II, da Constituição quanto ao regime jurídico da remuneração do concessionário do serviço público. A remuneração passa a ter a natureza de tarifa (não tributária), ao contrário da taxa aplicável no caso de prestação de serviços públicos por regime diverso dos de concessão ou permissão.

Esse raciocínio independe da natureza compulsória ou não da utilização dos serviços. Trata-se de deveres absolutamente dissociados, o de utilizar compulsoriamente o serviço e o de pagar a tarifa correspondente. A qualificação jurídica da cobrança como tarifa tem em vista, como se apontou, a tutela de interesses diversos, relacionados com a intangibilidade da equação econômico-financeira do contrato de concessão.

Nesse passo, note-se que o art. $7^{0}$, III, da Lei $n^{0} 8.987 / 95$ não estabeleceu liberdade plena de escolha por parte do usuário dos serviços concedidos. Não se presta como argumento acerca da impossibilidade de a lei tornar obrigatória a utilização do serviço concedido.

Em primeiro lugar, a redação do art. $7^{9}$, III, da Lei $\mathrm{n}^{0} 8.987$ foi modificada pela Lei $\mathrm{n}^{\circ}$ 9.648/98, passando a definir como direito do usuário “obter e utilizar $o$ serviço, com liberdade de escolha entre vários prestadores de serviço, quando for o caso, observadas as normas do poder concedente". O próprio texto da lei restringiu a noção de liberdade de escolha para pretender aplicá-la apenas quando houver vários prestadores (podendo o usuário optar por qualquer deles). $\mathrm{O}$ art. $9^{\circ}, \S 1^{\circ}$, da Lei $n^{\circ}$ $8.987 / 95$, em sua nova redação, também confirma que a concessão do serviço não depende da existência de via alternativa gratuita exceto se especificamente determi-

so Concessōes... p. 144.

51 Concessöes... p. 144 
nado por lei. Esse dispositivo confirma a viabilidade da imposição jurídica ou material (por ausência de alternativa) da compulsoriedade na utilização do serviço concedido.

Além disso, a compulsoriedade da utilização do serviço público é apenas um reflexo da compulsoriedade de prestação do serviço pelo Poder Público. A adoção do regime de concessão não altera o dever do Poder Público de prestar o serviço. Não é impedimento, portanto, à adoção de critério de compulsoriedade dos serviços (desde que, evidentemente, haja fundamentos para a instituição desse dever). No mesmo passo, a compulsoriedade não modifica o regime de cobrança de tarifa para taxa.

Note-se que, mesmo antes da alteração legislativa produzida pela Lei $\mathrm{n}^{0}$ 9.648/98, Marçal Justen Filho já apontava que "Existem serviços públicos compulsórios, na acepção de que o particular tem o dever de valer-se deles, em vista do interesse da coletividade. As hipóteses são excepcionais, em face dos princípios que estruturam um Estado Democrático de Direito. Assim, a ligação das residências à rede de água e esgoto não retrata uma livre escolha para os particulares." 52

É relevante perceber, porém, que a orientação do Supremo Tribunal Federal acima referida permanece em vigor. A Súmula no 545 do Supremo Tribunal Federal adota precisamente a noção de compulsoriedade como critério discriminador de taxas e tarifas. Pressupõe que a imposição de utilização de um serviço, acompanhada da previsão de que o serviço deve ser pago, corresponde à instituição (indevida) de um tributo (taxa) correspondente ao preço do serviço ${ }^{53}$.

Parece-nos que o critério da compulsoriedade para a distinção entre taxas e tarifas não é compatível com o art. 175 da Constituição Federal, que prevê amplamente a realização de serviços públicos sob regime de concessão sem excepcionar os serviços de limpeza urbana. Também não é compatível com os objetivos e valores constitucionais, que, em certos casos, pressupõem a obrigatoriedade de utilização do serviço. O serviço de limpeza pública engloba uma variedade de atividades de fruição obrigatória pelos particulares.

\section{IX - O problema do inadimplemento dos usuários}

32. A cobrança do valor das tarifas dos usuários envolve dificuldades práticas, em vista da dispersão dos destinatários da cobrança. Especialmente em relação aos serviços relacionados com a remoção e tratamento de resíduos domiciliares, há uma multiplicidade de usuários obrigados ao pagamento de tarifas de valores unitários reduzidos.

$\$ 2$ Concessōes... pp. 134/135.

53 Sobre a inadequação do critério da compulsoriedade para discriminar impostos e taxas, confira-se NOVELLI. FLÁVIO BAUER. Taxa - Apontamentos sobre o seu regime jurídico, em Revista de Direito Tributário $\mathrm{n}^{\mathrm{Q}} 59$, p. 95 e seguintes. 
$\mathrm{O}$ art. $6^{\circ}, \S 1^{\circ}$. da Lei $\mathrm{n}^{\mathrm{o}} 8.987 / 95$ define que o serviço adequado pressupõe a sua continuidade. $\mathrm{O} \S 3^{0}$ do mesmo dispositivo ressalva que não se caracteriza a descontinuidade com a sua interrupção em face do inadimplemento do usuário. A regra, porém, contém uma exceção: a interrupção por inadimplemento é possível, desde que "considerado o interesse da coletividade".

Não é possível, mesmo diante da ausência de pagamento da tarifa correspondente, a interrupção da prestação de serviço público cuja ausência possa oferecer risco à coletividade. É o caso de, quando menos, algumas das atividades envolvidas nos serviços de limpeza urbana. $O$ inadimplemento do usuário não autorizará o concessionário a interromper o serviço mínimo indispensável para a manutenção da segurança e da saúde públicas.

Note-se que o limite mínimo aqui referido não corresponde ao mínimo caracterizador do serviço universal, referido no início deste trabalho. Trata-se de conceitos diversos. O serviço universal vai além do mínimo necessário à proteção da coletividade, buscando assegurar a realização de certos objetivos constitucionais em relação ao próprio usuário. $O$ inadimplemento do usuário pode permitir a redução do serviço até limites inferiores aos que caracterizam o serviço universal, preservando-se o interesse coletivo na realização de certas tarefas de limpeza urbana.

Sobre tema análogo, Marçal Justen Filho apontou que "a hipótese do inc. II não autoriza, porém, a suspensão de serviços obrigatórios, cuja prestação se faz no interesse público ou é essencial à dignidade da pessoa humana. Essa é a situação específica do fornecimento de água tratada e de coleta de esgotos. A instalação de rede de distribuição de água tratada e de coleta de esgotos não se faz como meio de satisfação do interesse individual dos usuários. Trata-se de instrumento de à saúde pública (...) Em suma, quando a Constituição Federal assegurou a dignidade da pessoa humana e reconheceu o direito de todos à seguridade, introduziu obstáculo invencível à suspensão de serviços públicos essenciais" 54 .

$\mathrm{O}$ doutrinador aponta que o inadimplemento pode conduzir apenas à cobrança compulsória (administrativa e judicial) do montante da tarifa ou, verificando-se a impossibilidade de pagamento, a supressão da cobrança de certos usuários e a elevação das tarifas dos demais. Parece-nos que essa solução poderia ser ofensiva ao princípio da isonomia, na medida em que o universo dos particulares atendidos pelo serviço não coincidisse com o universo dos cidadãos ligados por um vínculo de solidariedade social (art. 3ำ I, da Constituição Federal) aos que são incapacitados do pagamento. No caso do serviço de limpeza urbana, de natureza municipal, o vínculo de solidariedade social está presente em todos os atingidos pela cobrança da tarifa. A recomposição dos custos não cobertos em face da inadimplência de pessoas incapacitadas do pagamento pode ser realizada, em princípio, através da elevação das tarifas dos demais usuários.

33. Um mecanismo usual para a efetivação da cobrança das tarifas de limpeza urbana consiste em sua exigência de forma combinada com a cobrança de outros valores. Na prática das concessões de serviços de limpeza urbana, há a cobrança

54 Concessöes... p. 130 
conjunta com o lançamento de impostos municipais (IPTU) ou com as faturas de água ou de energia elétrica.

A cobrança conjunta apresenta nítidas vantagens em termos de estímulo ao pagamento. Porém, produz dificuldade jurídica derivada da aplicação da Lei $\mathbf{n}^{\mathbf{o}}$ 8.078/90 (Código de Defesa do Consumidor) segundo a orientação da Portaria n 3 , de 19 de março de 1999, da Secretaria de Direito Econômico. No item 3, a referida Portaria estabelece que se enquadram no art. 51 da Lei $\mathrm{n}^{0} 8.078 / 90$ as cláusulas que "permitam ao fornecedor de serviço essencial (água, energia elétrica, telefonia) incluir na conta, sem autorização expressa do consumidor, a cobrança de outros serviços. Excetuam-se os casos em que a prestadora de serviço essencial informe $e$ disponibilize gratuitamente ao consumidor a opçāo de bloqueio prévio da cobrança ou utilização dos serviços de valor adicionado".

Desse modo, a cobrança conjunta pressupõe a autorização expressa do usuário ou a indicação clara no instrumento de cobrança da possibilidade de o usuário não efetuar o pagamento da tarifa de limpeza pública em conjunto com a relativa a outro serviço. Caso contrário, a cobrança pode ser reputada abusiva para o fim do art. 51 da Lei no $8.078 / 90$.

\section{$\mathrm{X}-$ Conclusão}

34. O presente estudo destinou-se a discorrer acerca da evolução do regime de prestação de serviços públicos de limpeza urbana, na medida em que se reconhece ao Estado uma nova posição na economia. Pretendeu formular indagações e investigar possibilidades para o desenvolvimento da participação de risco do setor privado nas atividades de limpeza urbana.

Concluiu ser possível promover a regulação ampla do setor de limpeza urbana, com a definição de obrigações concretas de serviço público e a indicação de atividades competitivas a ser prestadas pela iniciativa privada mediante autorização do Poder Público (em vista de seu vínculo com o interesse coletivo, ainda que preservada a competição). As atividades não competitivas (tipicamente as de infra-estrutura e de universalização do serviço, envolvidas nas obrigações de serviço público) devem ser submetidas a controle mais estrito pelo Poder Público. Esse controle mais estrito pode materializar-se através da publicatio específica da atividade e de sua sujeição a regime de concessão ou permissão de serviço público. Essa não é, porém, a única forma de controle estrito. É possível a atribuição de obrigações de serviço público (mediante fiscalização, cominação de penalidades e outros mecanismos de controle) aos prestadores de serviço de limpeza urbana encarregados também da exploração das atividades competitivas do setor.

Essas definições legais cabem à lei de cada município no âmbito do seu território. $\mathrm{O}$ art. 23, parágrafo único, e o art. $24, \S \S 1^{\mathrm{o}}$ a $4^{\mathrm{o}}$, da Constituição Federal, estabelecem também a competência da União Federal (através de lei complementar ou de lei ordinária, respectivamente) para estabelecer normas gerais em relação a determinados aspectos do setor de limpeza urbana. 
De outro lado. o estudo buscou enfrentar alguns dos problemas concretos da concessão de serviços de limpeza urbana tal como atualmente configurada no Brasil, com especial referência ao entendimento dos Tribunais Superiores acerca de tais problemas como parâmetro concreto para orientação de decisões privadas neste setor da atividade econômica.

\section{XI - Bibliografia}

ARIÑO ORTIZ, GASPAR. Economia y Estado - crisis y reforma del sector público, Marcial Pons, Madrid, 1993 et al. El nuevo servicio público. Marcial Pons, 1997.

BANDEIRA DE MELLO, CELSO ANTÔNIO. Curso de Direito Administrativo. Malheiros. $11^{\mathrm{a}}$ ed. 1999.

CUÉTARA MARTÍNEZ, J. M DE LA. et al. El nuevo servicio público. Marcial Pons, 1997.

DI PIETRO, MARIA SYLVIA ZANELLA. Parcerias na Administração Pública. Atlas, 1996.

GRAU, EROS ROBERTO. A ordem econômica na Constituição de 1988. Malheiros. $3^{\mathrm{a}} \mathrm{ed}$.

JUSTEN FILHO, MARÇAL. Concessões de Serviços Públicos. Dialética. 1997. Comentários à Lei de Licitações e Contratos Administrativos. Dialética, $5^{\underline{a}}$ ed., 1998.

MARQUES NETO, FLORIANO AZEVEDO. Outorga de Concessão de Serviços de Limpeza Urbana por Consórcio Intermunicipal. Boletim de Direito Administrativo. v. 13, no 10 , outubro de 1997, pp. 681/687.

MUÑOZ MACHADO, SANTIAGO. Servicio público y mercado. Civitas, v. I, 1998. NOVELLI, FLÁVIO BAUER. Taxa - apontamentos sobre o seu regime jurídico. Revista de Direito Tributário, nº 59, p. 95. 